\author{
International Journal of Linguistics, Literature and Translation (IJLLT) \\ ISSN: 2617-0299 (Online); ISSN: 2708-0099 (Print) \\ DOI: 10.32996/ijllt \\ Journal Homepage: www.al-kindipublisher.com/index.php/ijllt
}

IJLLT

\title{
The Potential of Integrating Social Media in Saudi EFL Context
}

Sharifunnessa

Lecturer, Department of English, College of Science and Arts for Girls, Khamis Mushait, King Khalid University, KSA.

Corresponding Author: Sharifunnessa, E-mail: saseed@kku.edu.sa

ARTICLE INFORMATION ABSTRACT

Received: November 22, 2020

Accepted: January 14, 2021

Volume: 4

Issue: 1

DOI: $10.32996 /$ ijllt.2021.4.1.17

\section{KEYWORDS}

Social media, Language learning, EFL students, Saudi Arabia
Language learning is going through a new dimension with advancement of new technologies. Social media integration with language learning has added a new insight in this field. The main objective of this study is to determine the position of social media in Saudi Arabia and then verify the probability of its use in language learning. This study is based on quantitative method using a questionnaire to collect data from 50 randomly chosen female students and 10 teachers of King Khalid University. Two different structured questionnaires consisted of eight questions based on different satisfactory level of Likert scale was used among the learners and teachers to know their opinion. Primarily it was assumed that most of the students would not agree to use social media for language learning due to their highly conservative socio -cultural background. However, later on it was found that majority of the students showed their interest to engage social media with language learning for the betterment of their learning skills. They also agreed that social media application would increase their practical knowledge related to real life situations communication. Still a few of them showed disinterest to these intermingling initiatives and thus disagreed with this endeavor. This study suggests a careful implication of suitable language learning features of social media with the EFL students and thus encourage them to be involved actively in language learning procedure.

\section{Introduction}

In Saudi Arabia, plenty of people are enjoying the privileges of using internet. A recent statistics of infographics shows that almost 32.23 million people are using Internet in Saudi Arabia and among them 25 million are active social media users, which is $72.38 \%$ of the total population. Like many other developed countries, internet has also become an integral part of their life. This revolution of information technology also makes teaching and learning process much easier than before. Students get an easy access to online authentic materials and learn the language by themselves in real life situations. It also makes the non-native English teacher's task much easier because they can provide the model of the native language in the classroom whenever needed. Lee J, Lee $Y$ and Kim (2015) emphasized that using social media tools, such as Facebook, WhatsApp, Twitter, and YouTube build strong relationships among tutors and students and helps develop self-confidence. It also enhances direct communication, thereby increasing the speed of feedback, while supporting students and facilitating learning among peers. Mubarak (2016) supported the use of social media in education, as it provides more flexible language learning experiences through constructivism. Learning communities in Mubarak's view have significantly progressed from regular classroom to a computer-generated education environment in which learners come together in a virtual environment to exchange ideas, solve problems, explore opportunities and understand the world in a better way. One of the major advantages of social media is it can improve communication not only between students and teacher but also among students. The latter can use social networks to talk to each other about upcoming assignments or tests. They can get details from their classmates about materials that will be covered on a test or the requirements for one or more assignments. If students are having trouble with a certain topic, they can go to classmates on a social networking website to get assistance and catch up online. Similarly, as blogs and wikis involve the contribution of multiple users, these collaborative tools can successfully enhance interactivity among students (Lin \& Yuan, 2006). The study which was carried out by (Kaplan \& Heinlein, 2010) showed that in in Saudi Arabia, incorporating technology into second language learning classrooms is not something new. Many educators have already experimented it in their teaching to accomplish different types of tasks. As the students can access the social media from anywhere and anytime, they can explain their problems thoroughly and be able to get

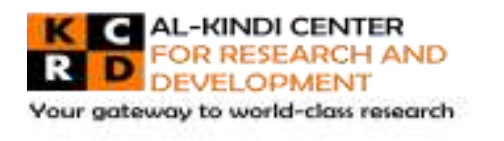

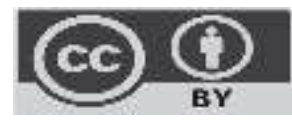

Published by Al-Kindi Center for Research and Development. Copyright (c) the author(s). This open access article is distributed under a Creative Commons Attribution (CC-BY) 4.0 license 
a detail feedback from the teacher as required. If needed, they can practice a lesson more than once and thus get a clear idea about it. Social media integration with language learning undeniably promotes self-learning opportunities, which lower the affective filter. Krashen (1981) mentioned that low affective filter: the condition when learners have high motivation, positive attitude, high self-confidence, and low anxiety, is necessary for language acquisition to take place. Creating conducive learning environment may lower down these variables ensuring learners' willingness to communicate. This study finds, though majority of students showed their interest in social media integration with language learning but some teachers and students still discouraged this process because of some external factors like unavailability of incessant internet connection in some rural areas, sensitive teachers' student relationship, lack of appropriate evaluation strategies, etc. It is possible to implement it to a very limited extent with minimum number of students.

\section{Literature Review}

\subsection{Social Media}

The term "social media" refers to the wide range of Internet based and mobile services that allow users to participate in online exchanges, contribute user created content or join online communities (Micheal Dewing,2010-p-1). "Social media has been broadly defined to refer to 'the many relatively inexpensive and widely accessible electronic tools that enable anyone to publish and access information, collaborate on a common effort, or build relationships." (Murthy \& Dhiraj, 2013). Social media has been described as "a group of Internet-based applications that build on the ideological and technological foundations of Web 2.0 and that allow the creation and exchange of user-generated content" (Kaplan \& Heinlein 2010). In other words, we can say that social media simply opens a new horizon of public communication and social gathering. It connects many people together at the same time, which was not possible before.

\subsection{Different Social Media tools for Language Teaching and Learning}

The students of Saudi Arabia use a lot of social networking site but still not all-social networking sites are suitable for language learning and teaching. Depending on the popularity of social media platforms and social chat apps and messengers, we can verify the probability of using YouTube, Facebook, Instagram, Twitter, Google+ and WhatsApp, Fb Messenger, Snapchat, Skype But in terms of feasibility and applicability, it is assumed that blogs and wikis are the most effective.

Blogs: Blog is an easily created, easily updateable website that allows an author (or authors) to publish instantly to the Internet from any Internet connection. (Richardson, 2009) So, a weblog or blog can be described as an online journal with one or many contributors. It is often labelled as an online journal where many participants can contribute. : Lina Lee (2011) a Professor of Spanish in the Department of Languages, Literatures and Cultures at the University of New Hampshire has used three types of blogs for the research project.

Wikis: A wiki is a set of interconnected and structured pages that provides a new dimension to information exchange and knowledge management. Wikis allow users to create repositories of knowledge, interact with their peers, and participate in projects as part of a group (Cole, 2009). According to Doolan (2011), "A wiki allows the networking of pages; therefore, pages may be linked to other pages or linked to other web sites and content, including images, sound, video, documents, and PowerPoint presentations. Using a wiki in this way has been found to support learners in creating dynamic learning environments." Doolan $(2007 a, 2007 b)$ has discussed about the role of the teachers in facilitating student learning with technologies like Wikis. She has designed the CLAT (Collaborative Learning through Assessment and Technology) pedagogical model that has been effectively used and evaluated in different academic disciplines over the course of five years for tertiary level education. The students can use a wiki in many different ways. They can use it for assignment submission, research projects, and add summaries of their thoughts from the suggested readings, building a collaborative annotated bibliography.

Facebook and twitter: In fact, Facebook and Twitter are among the most intensively investigated social media platforms for their credibility in education and various aspects of social media were examined in this research, focusing on such platforms because of their widespread and ever-increasing use across all age groups around the world, in particular among the younger generation. Additionally, these platforms were also incorporated into formal classrooms with the efforts of educators primarily aiming for student engagement (Abney, Cook, Fox, \& Stevens, 2018). Being the most popular social media platform ever (Smith \& Anderson, 2018), Facebook is reported to have features contributing to communication skills with peers and school or faculty members, participation, collaboration, peer support, commitment in educational activities (Tiryakioglu \& Erzurum, 2011). As an educational tool, it also enhances language teaching and learning and offers advantages not only for students but also for educators in that Facebook provides opportunities for engaging learners on tasks, for improving all four skills in English and increasing student motivation; however, it should be noted that educators need to have pre-planned objectives for Facebook to be utilized as an educational environment (Aydin, 2012; Lim \& Richardson, 2016; Rios \& Campos, 2015). 
Twitter provides a platform where a student can speak and contribute on any given topic without fear of mockery (Stewart, 2015). Regarding the language learning and teaching practices, it was shown that Twitter, with its microblogging feature, holds various uses at different language levels and settings with varying tasks in addition to offering interaction and communication with native users of the target language, as well as creating an awareness on noticing and exchange of the meaning (Hattem \& Lomicka, 2016). Additionally, Twitter as an authentic and dynamic education platform particularly for $\mathrm{L} 2$ learning contributes to cultural and socio pragmatic awareness of the learners, apart from improving their language skills while learning the language (Blattner $\&$ Dalola, 2018). Thus, Twitter accommodates a number of unique language learning opportunities for learners of language by offering interaction possibilities for practicing the language with native users.

WhatsApp: WhatsApp provides access to learning resources when teachers and students are separated by time and distance. (Honeyman \& Miller, 1993). Oxford University Press (2016) has shared some of their ideas of using WhatsApp for language learning. Five prominent features of WhatsApp have been used effectively to promote the language learning activities. Namely, they are text, photo, video Audio and emoji. Some of them can be suitable in the context of Saudi Arabia. WhatsApp Messenger is a proprietary, cross-platform, encrypted instant messaging client for smartphones. It uses the Internet to send text messages, documents, images, video, user location and audio messages to other users using standard cellular mobile numbers. WhatsApp is one of the commonly social network applications. It is used for social communication. The trend of this communication application is in the young generation. This application is easier than others that need several ways or steps to starts. Abdul Manan, Nanan. (2017) and Hamad (2017) conducted a study on first-year students at King Khalid University which revealed that WhatsApp enhances students 'language skills and developed their vocabulary.

\section{Instagram}

According to Wikipedia "Instagram (also known as IG) is a photo and video-sharing social networking service owned by Facebook." It is one of the top rated apps among the Saudi Young learners. However, it is not used for language learning for a large context but some of the educators tried to implement it in their ESL classroom. Mansor and Rahim (2017) applied Instagram in their language classroom and got a better effect related to students' participation and learning. The experimental teaching was conducted at the University Malaysia Terengganu with twenty students. The students were divided into 4 groups and each group were to set up their own Instagram account. Students were asked to create and video a communication situation based on a topic given. The students were given a time frame of one week to prepare their video and another one week to interact among themselves by giving comments on videos uploaded by each group and answer questions related to their experience interacting in Instagram. At the end of the study, it was found that the students loved to participate and interact with all the students involved in the task. Moreover, they claimed that using Instagram in language learning has motivated them to participate and boosted their confidence to communicate in English language.

Snap Chat: A mobile app that lets users take photos and short videos; users can decide how long data will be visible once opened, which can span of up to 10 seconds, and then supposedly disappears forever (Lomicka \& Lord, 2016). A small but growing number of teachers have begun using Snapchat as a way to push more learning outside of the classroom and onto their students' smartphones (Will, 2016). Many educators are using snapchat for language learning but still the ideas of incorporating it with language learning is not tangible. One high school library media specialist used Snapchat to help teach Homer's epic poem, The Odyssey, by having students represent Odysseus' journey in 10-second snaps (Lawrence, 2017). Students created characters with emojis, designed backgrounds with filters, and used face-swap to turn a student into a cyclops (Lawrence, 2017). Lawrence (2017) reported, "Excitement filled the library as our formerly reluctant students brought their storyboards to life" (p. 16). A French tutor in Ireland uses Snapchat with her students by adopting a different persona, Madame Menton, to give "colorful lessons with a dollop of good humor" (O'Brien, 2016, p.12). The tutor said that using Snapchat is very effective in reinforcing learning and helping to explain challenging concepts, as well as it keeps students engaged (O'Brien, 2016). O'Brien (2016) offered these tips for using snapchat stories for class: "reminders of upcoming homework, projects, or tests and as bite-sized lessons or as a way to make connections within the curriculum" and this tip for starting a discussion before class: "by asking an interesting question on Snapchat beforehand. This gives students time to think about the topic"

\subsection{Related works in the field of social media in Saudi Arabia:}

In Saudi Arabia, many language teachers have already applied social media as teaching tools in their teaching. Some researchers implemented it in their classroom, some of them carried out their research to know the attitudes, and perceptions of Saudi students. As Twitter and WhatsApp are the most popular social media platforms in Saudi Arabia, most of the EFL teachers of Saudi Arabia carried on their research about the potential benefits of implementing these in language learning process. Kutbi (2015) conducted a research on how undergraduate female students in the Kingdom of Saudi Arabia perceive the social media as a 
learning tool. In his study, he used twitter as the medium of an educational tool. The result of his study shows that a high majority of students were interested to admit social media for educational purpose. Ahmad (2015) explored the result of Twitter on EFL Saudi female writing and whether Twitter has an effect on: ideas and content, organization, voice and style. The study conducted by Asiri and Alqarni (2015) explored the positive outcome of using Twitter for EFL learning. The study was carried on among the high school students in Jeddah, inside and outside their schools. The study mentioned positive effect of Twitter in the learning and educational process. Few other studies also conducted in this related field aimed at knowing the attitudes and perception of Saudi learners regarding social media integration. Salih and Elsaid (2018) investigated the students' attitude towards the use of Social Media for Learning Purposes. Alsolamy, Fahd (2017) studied the language teachers' academics' attitudes, uses, motivations and concerns. Aifan (2015) examined Saudi Students' attitudes toward using social media to support learning. Most of the studies highlight that Social Media is a better avenue for the students to discover their learning potential as it gives an instant access to learning materials. They can practice frequently and repeatedly all productive skills denying the fear of embarrassment in front of their peer in traditional classroom. It is evident from the related work that social media can motivate the learners to develop their skill to the next level but it can never be a substitute of traditional classroom. There were some students who lived in rural areas and did not have uninterrupted internet connection, so it would not be an easy task for them to follow the lessons in social media. If even a single student misses the lesson or task, we cannot claim that the initiative is successful.

\section{Methodology}

\subsection{Participants}

The primary data for this present study was collected from both the teachers and students of the college of Arts and Science, Khamis Mushait King Khalid University. Among the participants, fifty students were doing their undergraduate under the department of English, and all of them were the female native speakers of Arabic. Among the ten teachers, all of them were teaching in the department of English, none of them was the native speakers of English. More over five of them were native Saudi and five of them were from different South Asian countries.

\subsection{Instruments}

The only instrument used for this study was structured questionnaire. For the students, two sets of questionnaires were used. The first set of questionnaires consisted of eight statements based on different satisfactory level of Likert Scale form disagree to agree and the second set of questionnaires consisted of 6 yes/no close ended questions. For the teachers, one set of questionnaires was used consisted of eight statements based on different satisfactory level of Likert Scale form disagree to agree.

\subsection{Data Collection Procedure}

The structured questionnaire sets were distributed among the teachers and students in person. They filled the questionnaire with necessary feedback which was effectively used for data analysis.

\subsection{Data Analysis Procedures}

The data collected from participants were analyzed through SPSS program for descriptive statistics (to calculate the means (M) of the items and standardized deviations (SD) to explain their responses to the questionnaire of this study.

\section{Results and Discussion}

The following explanations investigate each statement based on the content and variables. The first set of questionnaires was used to know the perceptions of students' by emphasizing the possible advantages, disadvantages of incorporating social media in language learning. In analyzing the statements, the participants were asked to rate their degree of agreement responding to eight statements using a five-point Likert-type scale. The Participants' answers were measured using a five-point Likert-type scale: one $=$ Strongly Agree, $2=$ Agree, $3=$ Neither Agree nor Disagree, 4= Disagree, 5= Strongly Disagree .

Table 1: Students' attitude towards the integration of social media in language learning

Means and standard deviation of Saudi students 'perceptions towards the use of social media for language learning.

\begin{tabular}{|l|l|l|l|}
\hline & N & Mean & Std. Deviation \\
\hline $\begin{array}{l}\text { 1. Learning English through social media will lower students' anxiety and increase } \\
\text { confidence. }\end{array}$ & 50 & 3.3600 & 1.19112 \\
2. Language learning would be more fun if it is integrated with social media. & 50 & 3.6200 & 1.14089
\end{tabular}




\begin{tabular}{|c|c|c|c|}
\hline $\begin{array}{l}\text { 3. Students will feel more comfortable to practice their writing and speaking skills in } \\
\text { social media. }\end{array}$ & 50 & 3.4600 & 1.32803 \\
\hline 4. Social networking sites will motivate the learners for self-learning. & 50 & 3.3800 & 1.21033 \\
\hline $\begin{array}{l}\text { 5. Students can choose suitable learning strategies if language is taught through social } \\
\text { media. }\end{array}$ & 50 & 3.5600 & 1.05289 \\
\hline 6. Students' will get more exposure to authentic English materials in social media. & 50 & 3.7000 & 1.05463 \\
\hline 7. Social media will promote a lack of seriousness among the students. & 50 & 3.1800 & 1.27279 \\
\hline $\begin{array}{l}\text { 8. The teachers -students' impartial relationship will be affected if social media is } \\
\text { included in language learning. }\end{array}$ & 50 & 2.9200 & 1.42628 \\
\hline Average & 50 & 3.3975 & 1.16952 \\
\hline
\end{tabular}

The first set of questionnaires was designed to know the Saudi students' opinion about the social media incorporation with language learning. Table 1 presented the descriptive statistics for these eight perception items, where last two statements indicated the negative impact of social media. Participants were asked to state their degree of agreement by responding to five items determining their attitudes. Participants' responses were measured employing a five-point Likert-type scale: $1=$ Strongly Disagree, $2=$ Disagree, $3=$ Neutral, $4=$ Agree, $5=$ Strongly Agree. A high score shows the more positive attitudes that the participants hold toward using social media to language learning, and a low score shows the least positive attitudes that the participants hold towards using social media to language learning. Participants' responses in this scale ranged from 3.70 to 2.92 , which indicates positive attitudes based on the Likert scale. To analyze the data, descriptive statistics were used in this questionnaire by calculating the means of the items and standardized deviations. The overall attitude of Saudi female students at King Khalid University toward using social media to support their learning was positive with a mean $M=3.39(S D=1.16)$. The analysis of students' attitude towards social media are like the following.1. Learning English through social media will lower students' anxiety and increase confidence $(M=3.36, S D=1.19) .2$. Language learning would be more fun if it is integrated with social media $(M=3.62, S D=1.14)$.3. Students will feel more comfortable to practice their writing and speaking skills in social media. $(M=3.46, S D=1.32)$. 4. Social networking sites will motivate the learners for self-learning. $(M=3.38, S D=1.21) .5$. Students can choose suitable learning strategies if language is taught through social media. $(M=3.56, S D=1.05)$. 6 . Students' will get more exposure to authentic English materials in social media. ( $M=3.70, S D=1.05)$. 7. Social media will promote a lack of seriousness among the students. $(M=3.18, S D=1.27) .8$. The teachers -students' impartial relationship will be affected if social media is included in language learning. $(M=2.92, S D=1.42)$. This result clearly exhibits that the highest number of students agreed that they would get more exposure to authentic materials in social media $(M=3.70)$.And the same time a significant number of students also agreed that social media communication among the students and teachers would affect the unbiased relationship between teachers and students. $(M=2.92)$. Results show that the participants think that they would face less anxiety and be more confident and motivated for self-learning in social media. At the same time, they enjoy language learning, feel free to share their speaking, and writing exercise through this network. However, a number of them think that social media will make the learning informal and therefore causes lack of seriousness and sometimes too much informal relationship between teachers and students can hinder the academic environment of learning. Therefore, the researcher feels that though they show positive and welcoming attitude towards the use of social media but overall, they are not interested to cross the threshold of formal academic environment.

Table 2: Saudi students' background check to verify the probability of using social media in language learning Means and standard deviation of Saudi students 'perceptions towards the use of social media for language learning.

\begin{tabular}{|l|l|l|l|}
\hline & $N$ & Mean & Std. Deviation \\
\hline 1. Do you have $24 / 7$ internet connection at home and outside? & 50 & 1.9800 & .14142 \\
2. Do you use social media to keep contact with your friends and families? & 50 & 2.0000 & .00000 \\
3. Do you chat with others in English? & 50 & 1.1800 & .38809
\end{tabular}


4. Have you ever been taught any course with the help social media?

5.Do you think social media will add a new dimension in language learning

\begin{tabular}{|l|l|l}
50 & 1.7800 & .41845 \\
50 & 1.9000 & .30305 \\
50 & 1.2000 & .40406 \\
50 & 1.6733 & .10627 \\
& & \\
\hline
\end{tabular}

6. Are you connected with your teacher through social media?

Average

The second set of questionnaires in table:2 was intended to know the Saudi students' background information to verify the probability of social media incorporation in language learning. Table 2 showed the descriptive statistics of six close-ended questions where the students were asked to give their feedback with yes/no. Participants' responses were measured by using $Y e s=2$ and $\mathrm{No}=1$ in measurement value. To explain the data, descriptive statistics were used in this questionnaire by calculating the means of the items and standardized deviations. The overall statistics of the background of Saudi female students at King Khalid University shows that they were almost ready to accept the innovation in language learning field with a mean $(M=1.67, S D=.10)$. The analysis of students' background information for the implementation of social media in language learning field are like the following. 1. Do you have $24 / 7$ internet connection at home and outside? $(M=1.98, S D=.141) .2$. Do you use social media to keep contact with your friends and families? $(\mathrm{M}-2, \mathrm{SD}=.00) .3$. Do you chat with others in English? $(\mathrm{M}=1.18, \mathrm{SD}=.38) .4$. Have you ever been taught any course with the help social media? $(\mathrm{M}=1.78, \mathrm{SD}=.41) .5$.Do you think social media will add a new dimension in language learning $(\mathrm{M}=1.90, \mathrm{SD}=.30)$. 6 . Are you connected with your teacher through social media? $(\mathrm{M}=1.2, \mathrm{SD}=.40)$.From the analysis, it is evident that almost all students had social media account and incessant internet connection, which is highly positive for the application of social media use in language learning. Nevertheless, it is a matter of concern that they hardly used social media tools for language learning, especially to chat with others.

Table 3: Teachers' attitude towards the integration of social media in language learning

Means and standard deviation of Saudi students 'perceptions towards the use of social media for language learning.

\begin{tabular}{|c|c|c|c|}
\hline & $\mathrm{N}$ & Mean & Std. Deviation \\
\hline $\begin{array}{l}\text { 1.I use internet in the classroom for language teaching } \\
2 . I \text { have accounts in different social media } \\
\text { 3.I am connected with my students through social media } \\
4 . I \text { like the idea of using social media for language teaching } \\
5 . \text { share different language learning materials with my students through } \\
\text { social media } \\
\text { 6.Social media integration will make the class more interesting and } \\
\text { interactive } \\
\text { 7.I believe that by using social media students can enhance their practical } \\
\text { language skills } \\
8 . \text { Students can utilize their time effectively if they learn the language } \\
\text { through social media } \\
\text { Average }\end{array}$ & $\begin{array}{l}10 \\
10 \\
10 \\
10 \\
10\end{array}$ & $\begin{array}{l}3.1000 \\
4.4000 \\
3.6000 \\
3.3000 \\
3.1000 \\
3.0000 \\
3.6000 \\
3.7000 \\
3.4429\end{array}$ & $\begin{array}{l}1.37032 \\
.69921 \\
1.42984 \\
1.49443 \\
1.52388 \\
1.56347 \\
1.50555 \\
1.49443 \\
1.31009\end{array}$ \\
\hline
\end{tabular}

In table 3, the questionnaires were constructed to know the Saudi ESL teachers 'opinion regarding the social media assimilation with language learning. Table 3 presented the descriptive statistics for these eight perception statements. The teachers were asked to state their degree of agreement by responding to these eight statements. Their responses were measured employing a five-point Likert-type scale: $1=$ Strongly Disagree, $2=$ Disagree, $3=$ Neutral, $4=$ Agree, $5=$ Strongly Agree. A high score exhibits 
the more positive attitudes that the teachers expressed towards using social media in language learning, and a low score shows the least positive attitudes that the teachers hold towards this. The teachers' in this scale ranged from 4.40 to 3.00 , which indicates an overall positive attitude based on the Likert scale. To examine the data, descriptive statistics were used in this questionnaire by calculating the means of the items and standardized deviations. The overall attitude of Saudi female teachers of King Khalid University towards using social media in their language teaching was positive with a mean of $(M=3.44(S D=1.31)$. The analysis of students' attitude towards social media are like the following. 1. I use internet in the classroom for language teaching. (M=3.10, $\mathrm{SD}=1.37)$. 2. I have accounts in different social media $(M=4.40, S D=.699)$. 3 . I am connected with my students through social media. $(M=3.60, S D=1.42)$. 4. I like the idea of using social media for language teaching. $(M=3.30, S D=1.49)$. 5 . I share different language learning materials with my students through social media $(M=3.10, S D=1.52)$. 6 . Social media integration will make the class more interesting and interactive. $(M=3.00, S D=1.56) .7$. I believe that by using social media students can enhance their practical language skills. $(\mathrm{M}=3.60, \mathrm{SD}=1.50)$.

\section{Conclusions}

This study focuses on the usage of social media for language learning and thus tries to determine the position of social media in the context of Saudi Arabia. In Saudi Arabia, all the classrooms are well equipped with modern technological support. The students are also very apt in using technologies. Therefore, it is estimated by the researcher that the students would obviously enjoy the implementation of new teaching techniques to enhance their language learning abilities. In this study, it is well established that almost all the teachers and students gave their consent about the application of different language learning strategies with the help of social media. They also deem that it will add a new dimension in their daily tedious teacher centered classroom. Some teaching strategies, which are not possible to apply in the traditional classroom, can be possible to execute with the help of social media. This will be enjoyable and at the same time stress free for English language learners of Saudi Arabia. However, still there are negative attitudes shown by the students so a further research might be conducted about the negative impact of social media for language learning if it is not implemented wisely.

\section{References}

[1] Abney, A. K., Cook, L. A., Fox, A. K., \& Stevens, J. (2018). Intercollegiate Social Media Education Ecosystem. Journal of Marketing Education. https://doi.org/10.1177/0273475318786026

[2] Aifan H A. (2015).Saudi Students' attitudes toward using social media to support learning [An unpublished doctoral thesis]. University of Kansas.

[3] Alsolamy, Fahd (2017). Social networking in higher education: academics' attitudes, uses, motivations and concerns [PhD thesis]. Sheffield Hallam University. http://shura.shu.ac.uk/information.html

[4] Asiri, A., \& Alqarni, M. (2015). Twitter as a tool for English learning: The case of high schools students in Jeddah. King Abdul-Aziz University, Faculty of Arts and Humanities, Department of European Languages \& Literature.

[5] Aydin, S. (2012). A review of research on Facebook as an educational environment. Educational Technology Research and Development, 60(6), 1093-1106. https://doi.org/10.1007/s11423-012-9260-7

[6] Blattner, G., \& Dalola, A. (2018). I Tweet, You Tweet, She Tweets: Enhancing the ESL Language Learning Experience through Twitter. International Journal of Computer-Assisted Language Learning and Teaching, 8(2), 1-19.

[7] Cole, M. (2009) Using Wiki Technology to Support Student Engagement: Lessons from the Trenches. Computers \&Education, 52, 141-146. http://dx.doi.org/10.1016/j.compedu.2008.07.003.

[8] Dewing, M. (2010). Social Media;An introduction. Library of Parliament.

[9] Dhiraj, M. (2013). Twitter: Social communication in the twitter age. Cambridge: Polity, 7-8.

[10] Doolan, M A. (2007a) Our Learners are the Net Generation Growing up in a Digital World. How then do we Engage with and Support this Type of Learner?'). In Proceedings of the 6th European Conference on e-Learning, Copenhagen Business School, Copenhagen, Denmark 4-5 October 2007

[11] Doolan, M. A. (2011). Developing Pedagogy: Role of the Tutor in Enabling Student Learning through the use of a Wiki. Educating Educators with Social Media. 1, 189-205.

[12] Doolan, MA. (2007b). Setting up online collaborative learning groups using Wiki technology - a tutors' guide. Educational Developments. The magazine of the Staff and Educational Development Association Ltd (SEDA), 8(2), 12-14

[13] Hamad, M. M. (2017). Using WhatsApp to enhance students' learning of English language"Experience to Share." Higher Education Studies, 7(4), 74-87. http://doi.org/10.5539/hes.v7n4p74

[14] Hattem, D., \& Lomicka, L. (2016). What the Tweets say: A critical analysis of Twitter research in language learning from 2009 to 2016. E-learning and Digital Media, 13(1-2), 5-23.

[15] Honeyman, M; Miller, G. ( 1993). Agriculture distance education: A valid alternative for higher education?. Proceedings of the 20th Annual National Agricultural Education Research Meeting: 67-73

[16] Kaplan, A. M., \& Haenlein, M. (2010). Users of the world, unite! The challenges and opportunities of Social Media. Business horizons, 53(1), 5968.

[17] Kaplan, Andreas M, \& Haenlein, Michael. (2010). Users of the world, unite! The challenges and opportunities of Social Media. Business horizons, 53(1), 59-68.

[18] KRASHEN, S. (1981). Second Language Acquisition and Second Language Learning. Oxford: Pergamon Press. 
[19] Kutbi, A. (2015). How Undergraduate Female Students in the Kingdom of Saudi Arabia Perceive Social Media as a Learning Tool: An Exploratory Study" (2015). Electronic Theses and Dissertations. 5290. https://scholar.uwindsor.ca/etd/5290

[20] Lawrence, A. (2017). An epic poemala Snapchat. School Library Journal, 63(2), 16.

[21] Lee, J., Lee, Y., \& Kim, M. H. (2015). Perceptions of teachers and students towards the educational application of SNS and its educational effects in middle school class. Turkish Online Journal of Educational Technology, 14(4), 124-134.

[22] Lee, L. (2011). Blogging: Promoting learner autonomy and intercultural competence through study abroad. Language Learning \& Technology, 15(3), 87-109.

[23] Lim, J., \& Richardson, J. C. (2016). Exploring the effects of students' social networking experience on social presence and perceptions of using SNSs for educational purposes. Internet and Higher Education, 29, 31- 39. https://doi.org/10.1016/j.iheduc.2015.12.001

[24] Lin, H. T., \& Yuan, S. M. (2006, July). Taking blog as a platform of learning reflective journal. In International Conference on Web-Based Learning (pp. 38-47). Springer, Berlin, Heidelberg.

[25] Lomicka, L., \& Lord, G. (2016). Social networking and language learning. In F. Farr \& M. Murray (Eds.), The Routledge handbook of language learning and technology (pp. 255-268). New York: Routledge.

[26] Manan, N. A. (2017). Whatsapp mobile tool in second language learning. Indonesian EFL Journal, 3(1), 87-92.

[27] Mansor, N., \& Rahim, N. A. (2017). Instagram in esl classroom. Man In India, 97(20), 107-114.

[28] Mubarak, A.A.A., 2016, 'Learning English as a second language through social media: Saudi Arabian tertiary context', International Journal of Linguistics 8(6), 112-127.

[29] O'Brien, C. (2016, 13 December). A new way to teach the Snapchat generation: Some teachers are using the social media app as an unlikely way to boost traditional teaching methods. Irish Times, 12

[30] Retrieved from http://blogs.edweek.org/teachers/teaching_now/2016/06/teachers_snapchat_guide.html

[31] Richardson, W.(2009). Blogs, wikis, podcasts and other powerful web tools for classrooms. California: Corwin Press.

[32] Rios, J. A., \& Campos, J. L. E. (2015). The Role of Facebook in Foreign Language Learning. Revista de Lenguas Modernas, 23, 253-262. Retrieved from https://www.actfl.org/news/positionstatements/statement-the-role-technology-language-learning

[33] Said, A., \& Abd Elfatah, M. (2015). The effect of Twitter on developing writing skill in English as a foreign language. Arab World English Journal (AWEJ) Special Issue on CALL, (2).

[34] Salih, A. A. A., \& Elsaid, D. A. S. (2018). Students Attitude Towards the Use of Social Media for Learning Purposes (Case Study: Al-Baha University, College of Sciences \& Arts-Biljurashi). Journal of LIterature, Language and Linguistics, 50, 7.

[35] Smith, A., \& Anderson, M. (2018). Social Media Use in 2018. Retrieved from www.pewresearch.org

[36] Stewart, B. (2015). Open to influence: what counts as academic influence in scholarly-networked Twitter participation. Learning, Media and Technology, 40(3), 287-309.

[37] Tiryakioglu, F., \& Erzurum, F. (2011). Use of Social Networks as an Educational Tool. Contemporary Educational Technology, 2(2), 135-150. http://dergipark.gov.tr/cet/issue/25724/271433

[38] Will, M. (2016, 10 June). Teachers are starting to use Snapchat. Should you? Education Week Teacher. 